\title{
Body composition determined by six different methods in women bilaterally adrenalectomized for treatment of Cushing's disease.
}

\author{
Citation for published version (APA): \\ Kemink, S. A., Frijns, J. T., Hermus, A. R., Pieters, G. F., Smals, A. G., \& van Marken Lichtenbelt, W. D. \\ (1999). Body composition determined by six different methods in women bilaterally adrenalectomized for \\ treatment of Cushing's disease. Journal of Clinical Endocrinology \& Metabolism, 84(11), 3991-3999. \\ https://doi.org/10.1210/jc.84.11.3991
}

Document status and date:

Published: 01/01/1999

DOI:

10.1210/jc.84.11.3991

\section{Document Version:}

Publisher's PDF, also known as Version of record

\section{Document license:}

Taverne

Please check the document version of this publication:

- A submitted manuscript is the version of the article upon submission and before peer-review. There can be important differences between the submitted version and the official published version of record.

People interested in the research are advised to contact the author for the final version of the publication, or visit the DOI to the publisher's website.

- The final author version and the galley proof are versions of the publication after peer review.

- The final published version features the final layout of the paper including the volume, issue and page numbers.

Link to publication

\footnotetext{
General rights rights.

- You may freely distribute the URL identifying the publication in the public portal. please follow below link for the End User Agreement:

www.umlib.nl/taverne-license

Take down policy

If you believe that this document breaches copyright please contact us at:

repository@maastrichtuniversity.nl

providing details and we will investigate your claim.
}

Copyright and moral rights for the publications made accessible in the public portal are retained by the authors and/or other copyright owners and it is a condition of accessing publications that users recognise and abide by the legal requirements associated with these

- Users may download and print one copy of any publication from the public portal for the purpose of private study or research.

- You may not further distribute the material or use it for any profit-making activity or commercial gain

If the publication is distributed under the terms of Article 25fa of the Dutch Copyright Act, indicated by the "Taverne" license above 


\title{
Body Composition Determined by Six Different Methods in Women Bilaterally Adrenalectomized for Treatment of Cushing's Disease
}

\author{
S. A. G. KEMINK, J. T. M. FRIJNS, A. R. M. M. HERMUS, G. F. F. M. PIETERS, \\ A. G. H. SMALS, W. D. VAN MARKEN LICHTENBELT
}

Department of Medicine, Division of Endocrinology, University Hospital Nijmegen (S.A.G.K., A.R.M.M.H., G.F.F.M.P., A.G.H.S.), 6500 HB Nijmegen; and the Department of Human Biology, University of Maastricht (J.T.M.F., W.D.V.M.L.), 6200 MD Maastricht, The Netherlands

\begin{abstract}
In 14 women, aged $47.2 \pm 10.5 \mathrm{yr}$, bilaterally adrenalectomized for Cushing's disease $13.6 \pm 7.7 \mathrm{yr}$ before, all receiving conventional doses of glucocorticoid and mineralocorticoid substitution, body composition was studied with regard to body fat, body fat distribution, fat-free mass, and bone mineral density. The data were compared with those of 14 healthy women of similar age, body mass index, and menopausal state. Five different body composition measurement methods were compared, i.e. body densitometry by underwater weighing (UWW), total body water measurement by deuterium dilution ( $\mathrm{D}_{2} \mathrm{O}$ dilution), dual energy x-ray absorptiometry (DXA), bioelectrical impedance spectrometry (BIS), and skinfold measurements, using a four-component model (4C-model) as the reference method.

In the patients the percent body fat was significantly higher than that in the controls as determined by all methods, whereas fat-free mass was significantly lower when measured with the $4 \mathrm{C}$-model, UWW, $\mathrm{D}_{2} \mathrm{O}$ dilution, DXA, or BIS. Measured by DXA, the percent trunk fat, estimated as [fat mass of the trunk $(\mathrm{g}) /$ total fat mass $(\mathrm{g})$ ] $\times 100 \%$, was significantly higher in the patients than in the controls
\end{abstract}

$(39.3 \pm 6.4 \%$ and $29.9 \pm 7.8 \%$, respectively; $P<0.001)$. Measured by DXA, there was no difference in total bone mineral density between the groups. Differences between the $4 \mathrm{C}$-model, UWW, $\mathrm{D}_{2} \mathrm{O}$ dilution, and DXA for determination of percent body fat were rather small. Skinfold measurements and BIS results, however, deviated substantially from those obtained using the 4C-model.

The study indicates that adrenalectomized patients receiving conventional glucocorticoid substitution have increased body fat percentages with a centripetal fat distribution and lowered fat-free mass, but normal bone mineral density. Furthermore, the study indicates that for clinical practice, DXA, $\mathrm{D}_{2} \mathrm{O}$ dilution, UWW, and the $4 \mathrm{C}$-model can be used for determination of body composition in this patient group, whereas the more convenient bedside methods, BIS and skinfold measurements, did not give reliable results. We suppose that glucocorticoid overreplacement in adrenalectomized patients might be the cause of their abnormal body composition, although GH deficiency after pituitary surgery could have played a contributory role in some of the patients. (J Clin Endocrinol Metab 84: 3991-3999, 1999)
$\mathrm{B}$ EFORE THE era of transsphenoidal pituitary surgery, total adrenalectomy has been widely used to treat pituitary-dependent Cushing's syndrome. Today, total adrenalectomy is no longer the primary therapy for Cushing's disease, but there still remain patients in whom bilateral adrenalectomy is needed for cure of the disease, especially when pituitary surgery was unsuccessful. It is the clinical impression that patients bilaterally adrenalectomized for treatment of Cushing's disease have an abnormal body composition. Body composition, however, has never been studied with objective methods in this group of patients.

A variety of methods for measuring human body composition are available. Most of these methods are based upon the two-component model in which the body consists of two chemically distinct compartments, the fat and fat-free masses. In this model it is assumed that the fat-free compartment has a density of $1.1 \mathrm{~g} / \mathrm{cc}$ at $37 \mathrm{C}$ and a water content of $0.73 \mathrm{~L} / \mathrm{kg}$, whereas fat, which is supposed to be anhydrous, has a density of $0.9 \mathrm{~g} / \mathrm{cc}$ at $37 \mathrm{C}(1)$. Examples of

Received January 12, 1999. Revision received July 22, 1999. Accepted July 28, 1999 .

Address all correspondence and requests for reprints to: Dr. S. A. G. Kemink, Department of Medicine, Division of Endocrinology, University Hospital Nijmegen, P.O. Box 9101, 6500 HB Nijmegen, The Netherlands. methods using the two-component model are measurement of whole body density by underwater weighing (UWW), measurement of total body water by deuterium dilution ( $\mathrm{D}_{2} \mathrm{O}$ dilution), dual energy x-ray absorptiometry (DXA), bioelectrical impedance spectrometry (BIS), and measurement of skinfold thicknesses.

In the four-component model (4C-model) the human body is divided into four chemically distinct compartments: water, protein, bone mineral, and fat. This model overcomes uncertainties concerning the hydration fraction of the fat-free mass (FFM) and segregates protein from mineral. Therefore, this model circumvenes the need for some of the assumptions inherent to the two-component model regarding proportions and densities of different components of the FFM (2). One of the most reliable methods for determining body composition is that of Füller et al. (2), in which a four-component model is used, which combines the results of densitometry by UWW with those of measurement of bone mineral content by DXA, and total body water assessment by $\mathrm{D}_{2} \mathrm{O}$ dilution $(2,3)$. The regional distribution of body fat is a critical variable to consider in the clinical assessment of (former) Cushing's patients, as accumulation of fat in the central part of the body is associated with an increased incidence of cardiovascular morbidity and mortality (4).

In the present study we obtained body composition data, 
such as body fat, body fat distribution, FFM, and bone mineral density (BMD), in a group of women bilaterally adrenalectomized for Cushing's disease, all receiving conventional glucocorticoid and mineralocorticoid substitution, and we compared these data with those of healthy women of similar age, body mass index, and menopausal state. We compared the relatively costly and complicated mechanistic methods (UWW, $\mathrm{D}_{2} \mathrm{O}$ dilution, and DXA) with the fast and inexpensive descriptive bedside body composition measurement methods (BIS and skinfold) using the 4C-model (2) as the reference method.

\section{Subjects and Methods}

\section{Subjects}

Fourteen women, aged $47.2 \pm 10.5 \mathrm{yr}$ (mean $\pm \mathrm{SD}$; range, $28-60 \mathrm{yr}$ ) bilaterally adrenalectomized for pituitary-dependent Cushing's syndrome $13.6 \pm 7.7 \mathrm{yr}$ earlier (range, 2-27 yr) were studied. Clinical characteristics and medical therapy of these 14 patients are summarized in Table 1. Eight of them were postmenopausal, and 6 were premenopausal at the time of the study. Before adrenalectomy 7 of the 14 patients had undergone unsuccessful pituitary surgery, and 1 had undergone transsphenoidal cryocoagulation of the pituitary. Two others had undergone pituitary surgery because of Nelson's syndrome after adrenalectomy, 18 and 11 yr before this study; in the latter patient pituitary surgery was followed by radiotherapy with a total dose of 46 Gy. All patients had conventional doses of glucocorticoid (cortisone acetate, $\mathrm{n}=$ 10; hydrocortisone, $\mathrm{n}=1$; prednisone, $\mathrm{n}=2$; dexamethasone, $\mathrm{n}=1$ ) and mineralocorticoid substitution ( $9 \alpha$-fluorohydrocortisone, all). For comparison, the doses of the glucocorticoids were converted to hydrocortisone equivalents $(30 \mathrm{mg}$ hydrocortisone $=37.5 \mathrm{mg}$ cortisone acetate $=$ $7.5 \mathrm{mg}$ prednisone $=0.75 \mathrm{mg}$ dexamethasone). The daily dose of hydrocortisone equivalent at the time of the study was $27.3 \pm 7.9 \mathrm{mg}$ (mean $\pm \mathrm{SD}$ ), and that of $9 \alpha$-fluorohydrocortisone was $0.11 \pm 0.06 \mathrm{mg}$. At the time of the study four patients were adequately substituted with levothyroxine because of secondary hypothyroidism, seven used estrogens (as oral contraception or as replacement therapy), and two were treated with desmopressin because of diabetes insipidus. To evaluate the presence of GH deficiency, in 13 of the 14 patients a standard arginine provocation test $(0.5 \mathrm{~g} / \mathrm{kg}$ arginine- $\mathrm{HCl}$; maximal dose, $30 \mathrm{~g})$ was performed. Peak plasma GH levels after arginine are given in Table 1. None of the patients had received GH substitution therapy. Three patients were treated for hypertension. Fourteen healthy female controls, aged $46.8 \pm 11.1 \mathrm{yr}$ (mean \pm sD; range, $26-59 \mathrm{yr}$ ) and matched with individual patients for age, body mass index (BMI), and menopausal state, were recruited. Two of them used estrogens as oral contraception. Patients and controls were well matched for age, height, weight, and BMI, respectively (Table 2).

The study was approved by the ethics committee of the University Hospital of Nijmegen. All subjects gave informed consent after explanation of the aims and methods of the study.

\section{Determination of percent body fat $(\% B F)$ and FFM using the two-component model}

Measurement of whole body density by UWW. After measuring body density by UWW it is possible to determine body fat and FFM from the measured whole body density (1). This technique uses determination of body volume according to Archimedes' principle, which states that the volume of an object submerged in water equals the volume of water the object displaced. If one measures weight in air and weight in water, the difference, corrected for the density of the water corresponding to the water temperature at the time of the underwater weighing, is the apparent body volume. Patients and controls, therefore, were submerged in water, dressed in swimwear, for measuring weight in water and body volume. The measurement was performed in the fasted state during tidal volume respiration, and correction was made for residual lung volume during submersion. Residual lung volume was measured with the helium dilution technique using a lung volume meter.

Measurement of total body water (TBW) by $\mathrm{D}_{2} \mathrm{O}$ dilution. Measurement of TBW is a method that allows determination of body fat and FFM,

TABLE 1. Clinical characteristics and therapy of the 14 patients bilaterally adrenalectomized for Cushing's disease

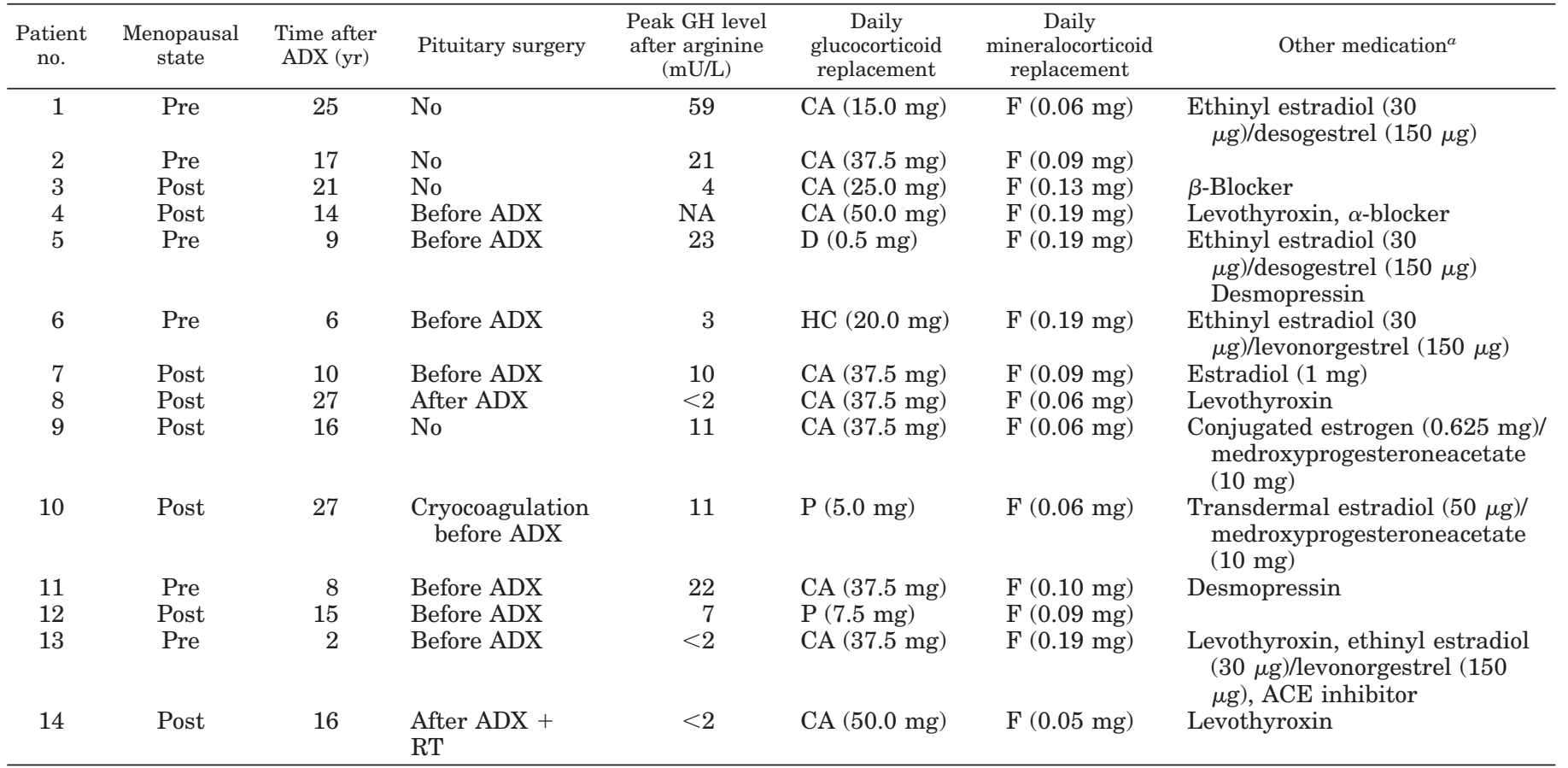

ADX, Bilateral adrenalectomy; RT, pituitary radiotherapy; CA, cortisone acetate; D, dexamethasone; HC, hydrocortisone; P, prednisone; F, 9- $\alpha$-fluorohydrocortisone; NA, not available.

${ }^{a}$ Doses are per day. 
TABLE 2. Physical characteristics of the 14 adrenalectomized women and their controls

\begin{tabular}{|c|c|c|c|c|c|c|c|c|}
\hline \multirow[b]{2}{*}{ Subject no. } & \multicolumn{4}{|c|}{ Adrenalectomized patients } & \multicolumn{4}{|c|}{ Controls } \\
\hline & Age (yr) & $\mathrm{Ht}(\mathrm{m})$ & Wt (kg) & $\begin{array}{c}\mathrm{BMI} \\
\left(\mathrm{kg} / \mathrm{m}^{2}\right)\end{array}$ & Age (yr) & $\mathrm{Ht}(\mathrm{m})$ & Wt (kg) & $\begin{array}{c}\mathrm{BMI} \\
\left(\mathrm{kg} / \mathrm{m}^{2}\right)\end{array}$ \\
\hline 1 & 44 & 1.59 & 59.7 & 23.6 & 40 & 1.63 & 56.4 & 21.2 \\
\hline 2 & 47 & 1.68 & 71.4 & 25.3 & 51 & 1.62 & 74.3 & 28.3 \\
\hline 3 & 55 & 1.62 & 76.4 & 29.1 & 53 & 1.63 & 76.0 & 28.6 \\
\hline 4 & 57 & 1.62 & 71.0 & 27.1 & 59 & 1.62 & 70.7 & 26.9 \\
\hline 5 & 28 & 1.57 & 62.9 & 25.5 & 26 & 1.70 & 68.4 & $23.7^{a}$ \\
\hline 6 & 35 & 1.75 & 62.2 & 20.3 & 37 & 1.75 & 59.6 & 19.4 \\
\hline 7 & 55 & 1.61 & 61.2 & 23.6 & 57 & 1.58 & 55.0 & 22.0 \\
\hline 8 & 51 & 1.71 & 71.6 & 24.5 & 48 & 1.70 & 75.8 & 26.2 \\
\hline 9 & 52 & 1.64 & 63.2 & 23.5 & 55 & 1.63 & 65.1 & 24.5 \\
\hline 10 & 58 & 1.70 & 69.1 & 23.9 & 58 & 1.61 & 64.1 & 24.7 \\
\hline 11 & 35 & 1.63 & 54.3 & 20.4 & 34 & 1.67 & 55.2 & 19.8 \\
\hline 12 & 60 & 1.66 & 70.3 & 25.5 & 57 & 1.69 & 72.1 & 25.3 \\
\hline 13 & 33 & 1.58 & 57.5 & 23.0 & 31 & 1.70 & 59.5 & $20.6^{a}$ \\
\hline 14 & 51 & 1.65 & 74.7 & 27.4 & 49 & 1.66 & 70.0 & 25.4 \\
\hline Mean (SD) & $47.2(10.5)$ & $1.64(0.05)$ & $66.1(6.8)$ & $24.5(2.5)$ & $46.8(11.1)$ & $1.66(0.05)$ & $65.9(7.7)$ & $24.0(3.0)$ \\
\hline
\end{tabular}

${ }^{a}$ Two of the controls used estrogens.

assuming that water is not present in stored fat and that water occupies a relatively fixed fraction $(73.2 \%)$ of the FFM $(5,6)$. TBW was determined by $\mathrm{D}_{2} \mathrm{O}$ dilution, as described previously (7). Before the intake of a single oral dose of a known amount of deuterium, a urine sample was taken for deuterium (background) measurement. After an overnight equilibration period of $10 \mathrm{~h}(8)$, another urine sample was taken for deuterium (enriched) measurement. Subjects did not eat or drink between the time the deuterium was taken and the enriched urine samples were obtained. Deuterium in urine was measured by mass spectrometry (7).

DXA. Total bone mineral content (TBMC) and soft tissue composition of the body were measured with dual energy $\mathrm{x}$-ray absorptiometry (model DPX, Lunar Corp., Madison, WI) as described previously (9). We used the medium scan speed $(80 \mathrm{~mm} / \mathrm{s})$ with a resolution of $4.8 \times 9.6 \mathrm{~mm}$. For determination of soft tissue composition, total soft tissue (grams), fat tissue (grams), lean tissue (grams), and bone mineral content (grams) were measured in the total body and in the trunk. Moreover, total BMD (TBMD; grams per $\mathrm{cm}^{2}$ ) was calculated using Lunar Corp. software (version 1.3z).

BIS. With bioelectrical impedance measurements of the body at different frequencies (BIS) it is possible to discriminate between the extracellular water compartment (ECW) and the intracellular water compartment (ICW) of the body, as tissue impedance at low frequencies is highly correlated with the ECW and at high frequencies with the total body water compartment (TBW) (10). The prediction of ECW and TBW using the impedance of ECW and TBW depends on the underlying theory. We used the general mixture theory based on emulsion sciences. This theory includes properties of both the conducting material and the nonconducting material in the suspension. An extensive explanation of this theory is described by De Lorenzo et al. (10) as well as by Hanai (11). FFM can be estimated from the results of BIS, assuming a fixed hydration of the FFM of $0.73 \mathrm{~L} / \mathrm{kg}$. In patients and controls BIS was measured with a Xitron 4000 Multi-Frequency Bio-Impedance Analyzer (Xitron Technologies, San Diego, CA) at frequencies of $5-500 \mathrm{kHz}$, as described previously $(10,12)$. A tetrapolar arrangement of gel electrodes was used, placed on hand, wrist, ankle, and foot at the right side of the body.

Skinfold thicknesses. Skinfold thicknesses were measured to the nearest $0.2 \mathrm{~mm}$ at four sites, i.e. biceps, triceps, subscapular, and suprailiac, with a Holtain Ltd. caliper as described previously (1). Because body density is not linearly related to sc fat mass, mathematical transformation of the sum of skinfold thicknesses and correction for gender and age was performed as described by Durnin and Womersley (13) for prediction of $\% B F$.

\section{Determination of $\% B F$ and FFM using the $4 C$-model}

Body composition was also estimated by the $4 \mathrm{C}$-model according to Füller, combining the measurements of body density (UWW), total body water ( $\mathrm{D}_{2} 0$ dilution), and bone mineral content (DXA). Classical twocompartment models (fat and FFM), such as underwater weighing, are limited by assumptions regarding the constancy of composition of the FFM. The 4C-model (fat, water, protein, and mineral), which is based on measurements obtained from densitometry, $\mathrm{D}_{2} \mathrm{O}$ dilution, and DXA, overcomes uncertainties concerning the hydration of the FFM and bone mineral content. The 4C-model incorporates direct measurement of TBMC, as well as the established measurements of body density and total body water. Densities of fat, protein, and TBMC are still assumed as well as the ratio of osseous to nonosseous mineral. From this description it is evident that the calculations of body fat by UWW and $\mathrm{D}_{2} \mathrm{O}$ dilution are not completely independent in the $4 \mathrm{C}$-model. Differences in outcome depend to a large extent on deviations from reference values with respect to the hydration of FFM and to the bone mineral fraction of FFM.

Total body fat was calculated according to the formula: fat $(\mathrm{kg})=$ $2.747 \mathrm{BV}-0.710 \mathrm{TBW}+1.460 \mathrm{TBMC}-2.050 \mathrm{Wt}$, where BV is body volume in liters (from UWW), TBW is total body water volume in liters (from $\mathrm{D}_{2} \mathrm{O}$ dilution), TBMC is total bone mineral content in kilograms (from DXA), and Wt is body weight in kilograms (2).

The density of the FFM was calculated according to the formula: $D_{\text {FFM }}$ $=(0.710 \mathrm{TBW}+3.050 \mathrm{Wt}-2.747 \mathrm{BV}-1.460 \mathrm{TBMC}) /(0.788 \mathrm{TBW}+$ $2.276 \mathrm{Wt}-2.050 \mathrm{BV}-1.621 \mathrm{TBMC}$; the abbreviations TBW, Wt, BV, and TBMC are defined above (2).

The hydration fraction of the FFM was calculated from the mass of TBW (from $\mathrm{D}_{2} \mathrm{O}$ dilution) and total body FFM, obtained from the 4Cmodel, according to the formula: hydration fraction $=\mathrm{TBW} /(0.715 \mathrm{TBW}$ $+3.070 \mathrm{Wt}-2.765 \mathrm{BV}-1.469 \mathrm{TBMC})$; the abbreviations TBW, $\mathrm{Wt}, \mathrm{BV}$, and TBMC are defined above (2).

\section{Determination of percent trunk fat (\%TF)}

We defined the fat mass of the trunk as the sc and the intraabdominal fat mass of the thoracic and abdominal parts of the body. The \% TF was estimated as [fat mass of the trunk $(\mathrm{g}) /$ total fat mass $(\mathrm{g})] \times 100 \%$, as measured with DXA as described above.

\section{Statistical analysis}

Wilcoxon's signed rank test was used to test the significance of differences between adrenalectomized patients and matched controls $(P)$. Spearman rank correlation coefficients were used to test relations between body fat compartments measured by different methods $\left(P^{*}\right)$. Stepwise regression analysis was used to determine the relationships between factors supposed to be related to body fat distribution. For assessing the agreement between different methods, the bias and limits of agreement (error) between the different methods were calculated according to the method described by Bland and Altman (14). All data are expressed as the mean $\pm \mathrm{SD}$. 


\section{Results}

\section{Percent body fat and FFM}

As shown in Table 3, the \%BF in the patients was significantly higher than in the controls, regardless of the method used. Figure $1 \mathrm{~A}$ shows that the $\% \mathrm{BF}$, as calculated by the 4C-model, was higher in the adrenalectomized patients than in their control subjects. FFM in patients was significantly lower than that in controls when measured with the $4 \mathrm{C}$ model, UWW, $\mathrm{D}_{2} \mathrm{O}$ dilution, DXA, or BIS. Skinfold measurement failed to distinguish the difference in FFM between both groups. In Fig. $1 B$ the results of FFM, calculated by the 4C-model, are given for the individual patient-control pairs. The hydration of the FFM in the patients $(0.77 \pm 0.02 \mathrm{~L} / \mathrm{kg}$; range, $0.73-0.80)$ was not different from that in controls $(0.76 \pm 0.01 \mathrm{~L} / \mathrm{kg}$; range, $0.74-0.78)$. There was no difference in $\% \mathrm{BF}_{\mathrm{DXA}}(39.3 \pm 5.2 \%$ and $39.7 \pm 3.5 \%$, respectively) or in FFM $_{\text {DXA }}(40.8 \pm 3.1$ and $38.2 \pm 3.5 \mathrm{~kg}$, respectively) between patients with peak plasma $\mathrm{GH}$ levels after arginine provocation of $10 \mathrm{mU} / \mathrm{L}$ or less and patients with GH levels greater than $10 \mathrm{mU} / \mathrm{L}$. Using a cut-off level for peak plasma GH of $15 \mathrm{mU} / \mathrm{L}$ after arginine provocation, there was also no difference in $\% \mathrm{BF}_{\mathrm{DXA}}(38.9 \pm 4.6 \%$ and $40.9 \pm 3.8 \%$, respectively) or in $\mathrm{FFM}_{\mathrm{DXA}}(40.9 \pm 2.8$ and $36.6 \pm 3.0 \mathrm{~kg}$, respectively) between the group with the lower and that with the higher GH levels.

\section{Regional fat distribution}

Measured by DXA, the \%TF in the patients was significantly higher than that in the controls $(39.3 \pm 6.4 \%$ and $29.9 \pm$ $7.8 \%$, respectively; $P<0.001$ ). In all patient-control pairs, except one, \% TF was higher in the patient than in the control subject (Fig. 1C). There was no statistically significant difference in $\%$ TF $(53.0 \pm 4.8 \%$ and $48.2 \pm 7.0 \%$, respectively) between patients with a $\mathrm{GH}$ level of $10 \mathrm{mU} / \mathrm{L}$ or less and patients with a GH level greater than $10 \mathrm{mU} / \mathrm{L}$ after arginine provocation or between patients with a GH level of $15 \mathrm{mU} / \mathrm{L}$ or less and patients with a GH level greater than $15 \mathrm{mU} / \mathrm{L}$ $(52.8 \pm 4.8 \%$ and $46.0 \pm 5.7 \%$, respectively). There was a statistically significant correlation between $\% \mathrm{TF}$ and $\% \mathrm{BF}$ in both patients and controls $\left(r=0.44 ; P^{*}<0.02\right)$. However, in a stepwise regression including the adrenalectomized state and $\% \mathrm{BF}$ as independent variables, only the adrenalectomized state (as a dummy variable) appeared to be included $(P<0.005)$, whereas \%BF did not, stressing the difference between the adrenalectomized patients and the controls with respect to body fat distribution $[\% \mathrm{TF} / \% \mathrm{BF}=7.89 \times \mathrm{D}+$ $0.1 \times \% \mathrm{BF}_{\mathrm{DXA}}+38.71$; $(\mathrm{D}=$ dummy variable for the adrenalectomized state)].

\section{$B M D$}

DXA measurement showed no difference in total BMD between patients and healthy controls (Table 3 and Fig. 1D) and no statistically significant correlation between BMD and $\% \mathrm{BF}$ or $\% \mathrm{TF}$.

\section{Comparison of the different body composition methods}

For comparison of the methods we pooled the data from patients and controls. To obtain information about the agreement of two different methods, we plotted the difference between the two methods against their mean (14). The 4Cmodel served as the reference method. The comparisons revealed no significant correlations between the differences in \%BF between the 4C-model and the mechanistic methods (UWW, $\mathrm{D}_{2} \mathrm{O}$ dilution, or DXA), on the one hand, and the size of the measurement, on the other hand, whereas those from the descriptive methods (BIS or skinfolds) were significantly negatively related to the average $\% \mathrm{BF}$ (Fig. 2, A-E, and Table 4 ). The bias of the 4C-model with the methods UWW and DXA, estimated by the average difference between methods, was not significantly different from zero. The SD of the differences between the 4C-model and DXA, however, was relatively high. The bias of the $4 \mathrm{C}$-model with $\mathrm{D}_{2} \mathrm{O}$ dilution was greater $(-3.2 \%)$, but the error between both methods was relatively small ( $2 \mathrm{SD}, 2.4 \%)$. In the patient group only, the bias of the 4C-model with skinfold measurements was $-9.9 \%$, and the error between both methods was $6.6 \%$,

TABLE 3. Percent body fat (\%BF), fat-free mass (FFM), and total bone mineral density (TBMD) in adrenalectomized patients and controls

\begin{tabular}{|c|c|c|c|c|}
\hline Method & $\begin{array}{l}\text { No. of } \\
\text { pairs }\end{array}$ & $\begin{array}{c}\text { Patients } \\
(\text { mean } \pm \mathrm{SD})\end{array}$ & $\begin{array}{c}\text { Controls } \\
(\text { mean } \pm \mathrm{SD})\end{array}$ & $P$ value \\
\hline UWW $(\%)$ & 11 & $41.7 \pm 5.6$ & $31.1 \pm 7.5$ & $<0.005$ \\
\hline $4 \mathrm{C}$ model $(\%)$ & 11 & $42.4 \pm 4.5$ & $31.7 \pm 6.7$ & $<0.005$ \\
\hline BIS $(\%)$ & 14 & $45.9 \pm 3.6$ & $39.1 \pm 4.1$ & $<0.005$ \\
\hline Skinfolds (\%) & 14 & $33.6 \pm 4.1$ & $30.5 \pm 3.9$ & $<0.05$ \\
\hline $\mathrm{D}_{2} \mathrm{O}$ dilution $(\mathrm{kg})$ & 12 & $39.1 \pm 3.1$ & $45.7 \pm 2.8$ & $<0.005$ \\
\hline DXA (kg) & 14 & $39.8 \pm 3.4$ & $44.5 \pm 2.2$ & $<0.005$ \\
\hline 4C model $(\mathrm{kg})$ & 11 & $37.1 \pm 2.5$ & $43.3 \pm 2.8$ & $<0.01$ \\
\hline BIS $(\mathrm{kg})$ & 14 & $35.6 \pm 3.1$ & $39.9 \pm 3.6$ & $<0.01$ \\
\hline Skinfolds $(\mathrm{kg})$ & 14 & $43.7 \pm 3.2$ & $45.6 \pm 4.3$ & NS \\
\hline Hydration of FFM (L/kg) & 11 & $0.77 \pm 0.02$ & $0.76 \pm 0.01$ & NS \\
\hline TBMD DXA $\left(\mathrm{g} / \mathrm{cm}^{2}\right)$ & 14 & $1.09 \pm 0.09$ & $1.11 \pm 0.06$ & NS \\
\hline
\end{tabular}

UWW, Underwater weighing; $\mathrm{D}_{2} \mathrm{O}$ dilution, deuterium dilution method; DXA, dual energy x-ray absorptiometry; $4 \mathrm{C}$ model, four-component model; BIS, bioelectrical impedance spectrometry; skinfolds, skinfold measurements. 


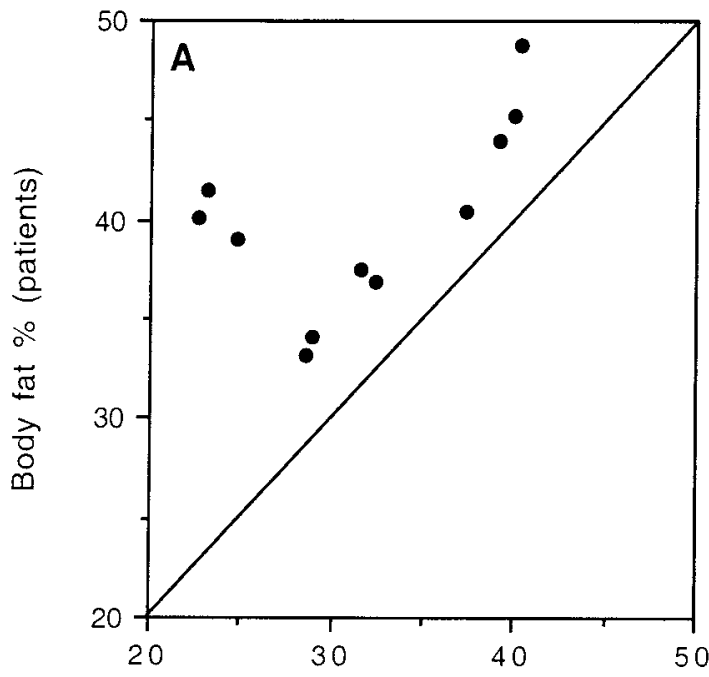

Body fat \% (controls)

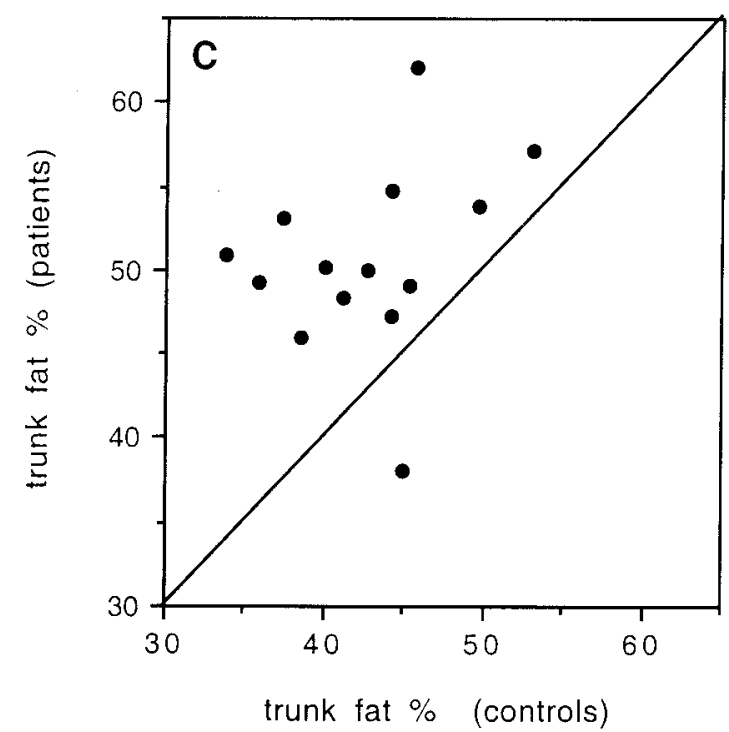

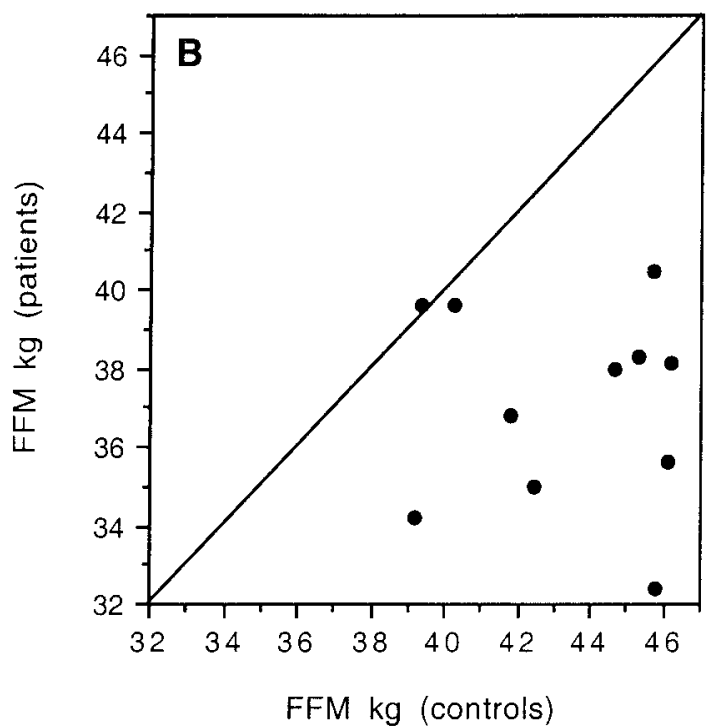

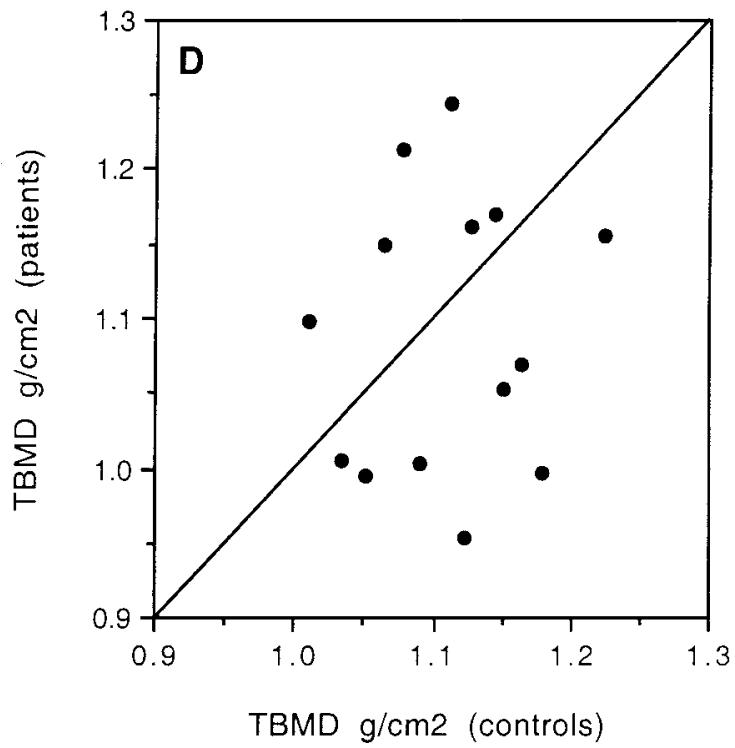

Fig. 1. A and B, \%BF (A) and FFM (B), calculated by the $4 \mathrm{C}$-model of Füller in 11 female adrenalectomized patients $v s$. $\% \mathrm{BF}$ and FFM in their individual controls matched for age, sex, BMI, and menopausal state. C, \% TF, defined as fat mass of the trunk (grams )/total fat mass (grams) measured by DXA, in 14 female adrenalectomized patients $v s . \% \mathrm{TF}$ in their individual controls. D, TBMD in 14 female adrenalectomized patients vs. TBMD in their individual controls.

whereas the bias of the 4C-model with BIS was not significant.

\section{Discussion}

In a group of 14 women adrenalectomized for Cushing's disease, conventionally substituted with gluco- and mineralocorticoids during periods up to $27 \mathrm{yr}$, body composition differed impressively from that in control women matched for age, body mass index, and menopausal state. The \%BF measured by the 4C-model as well as by five other methods was significantly higher in the former Cushing's patients. Correspondingly, FFM, an indicator of muscle mass, was significantly lower $(\sim 10 \%)$ in the adrenalectomized patients.
In the patients body fat distribution was also significantly different from that in controls, with higher percentages of truncal fat in the adrenalectomized patients.

To determine which body composition methods give reliable results in this specific patient group, we compared five different methods using the 4C-model of Füller (2) as the reference method. For determination of $\% \mathrm{BF}$, the differences between the 4C-model and the mechanistic methods (UWW, $\mathrm{D}_{2} \mathrm{O}$ dilution, and DXA) were not large. Of these methods the average difference was highest between the $\mathrm{D}_{2} \mathrm{O}$ dilution method and the $4 \mathrm{C}$-model $(-3.2 \%)$. The relatively low $\% \mathrm{BF}$ found with the $\mathrm{D}_{2} \mathrm{O}$ dilution method can be explained by the rather high hydration of FFM we found in this study. On the 

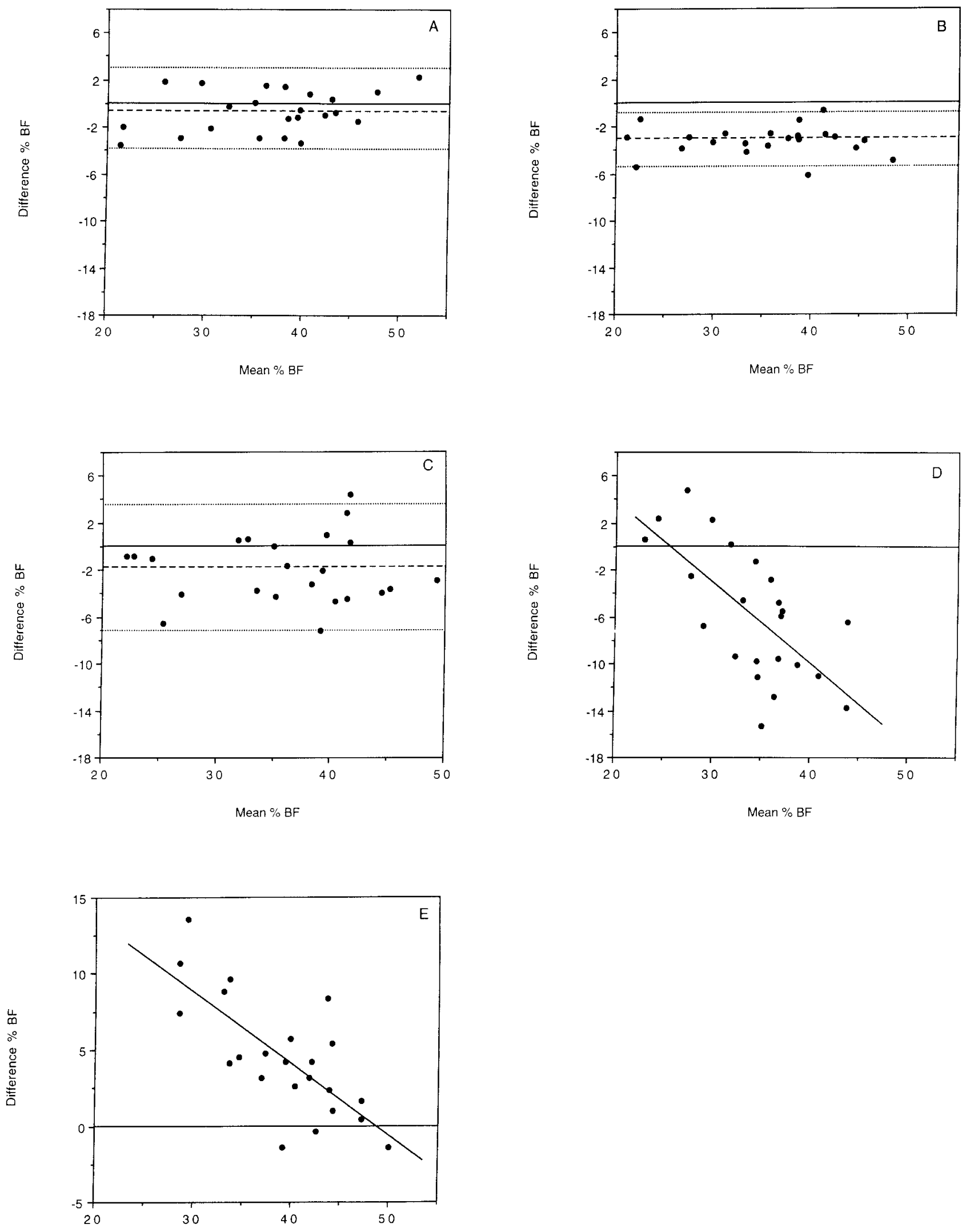

Mean \% BF

FIG. 2. Difference in $\% \mathrm{BF}$ between the two methods (alternatives A-E against the $4 \mathrm{C}$-model according to Füller) plotted against the means. Indicated is the mean difference (bias) and 2 SD (error). A, UWW; B, $\mathrm{D}_{2} \mathrm{O}$ dilution method; $\mathrm{C}, \mathrm{DXA} ; \mathrm{D}$, skinfold measurements; E, BIS. 
TABLE 4. Comparison of body composition techniques with the reference technique (4C model); regression analyses of the difference between respective methods and their mean

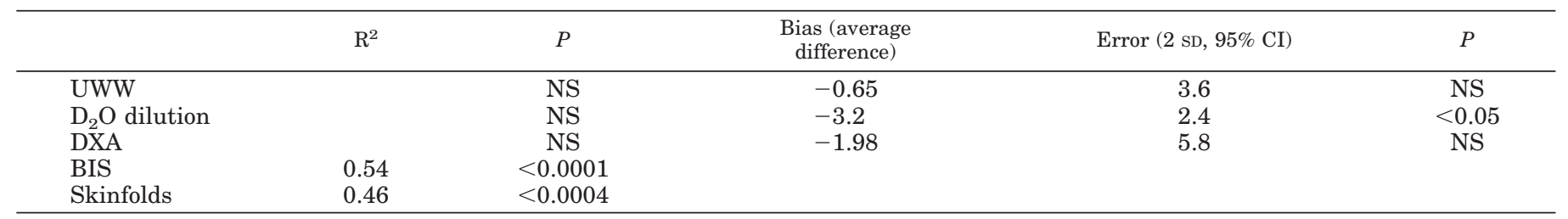

Given are the regression coefficient $\left(\mathrm{R}^{2}\right)$ and $P$ value. When there was no significant relation, bias (average difference between the methods) and error (2 SD or 95\% CI) are presented. 4C model, Four-component model; UWW, underwater weighing; $\mathrm{D}_{2} \mathrm{O}$ dilution, deuterium dilution method; DXA, dual energy x-ray absorptiometry; BIS, bioelectrical impedance spectrometry; skinfolds, skinfold measurements. The statistically significant regression coefficients of BIS and skinfolds disclose a significant relation between the differences in percent body fat of the two methods compared to the $4 \mathrm{C}$ model and the size of the measurement. This relation is compatible with disagreement between methods.

other hand, results from the descriptive methods, skinfold measurement and BIS, deviated substantially from results using the 4C-model. With respect to skinfold measurement, this deviation probably can be attributed to the peculiar body fat distribution in the patients. As patients have relatively more truncal body fat, skinfold measurements, of which only the iliac is in the truncal region, underestimated the $\% \mathrm{BF}$ in the patient group. Plotting of the difference in \%BF between the skinfold and the 4C-model against their means showed a significant correlation between both the difference and the mean. This discloses a disagreement between the methods. The higher the mean \%BF, the larger the discrepancy between the two methods. Comparison between the results from BIS and the 4C-model also reveals a significant correlation between the difference in \%BF by both BIS and the $4 \mathrm{C}$-model, on one hand, and the mean $\% \mathrm{BF}$, on the other hand. In our study total body water volumes were calculated from a general mixture theory $(10,11)$, using specific resistivities of the water compartments, rather than applying the common procedure in bioimpedance analyses of an empirically determined regression equation. The disagreement between the results from BIS and the 4C-model can be explained by these specific resistivities. It is, however, important to realize that these coefficients do not affect the correlation between the methods. The relation between the error and the mean of the measurements can be caused by differences in body shape or fat distribution, as with the skinfold measurements. On the other hand, specific resistivities of the water compartments may be different between patients and controls. From these data we conclude that UWW, DXA, and $\mathrm{D}_{2} \mathrm{O}$ dilution can be used for assessing the $\% \mathrm{BF}$ in adrenalectomized patients. The two more convenient bedside methods, BIS and skinfold measurements, did not give reliable results.

Several explanations may be offered for the increased \%BF and truncal obesity in the former Cushing's patients. Hypothyroidism as the cause of the increased \%BF is unlikely. Although four patients had secondary hypothyroidism after pituitary surgery, they were adequately substituted with levothyroxine, having plasma free $\mathrm{T}_{4}$ levels in the normal range. In the other patients euthyroidism was documented. Furthermore, six patients were treated with oral and one with transdermal estrogens as contraceptive or replacement therapy, whereas in the control group only two women used estrogens. It is unlikely, however, that the use of estrogens could be responsible for the centripetal obesity in the patient group. In postmenopausal women estrogen replacement therapy is not associated with weight gain and central obesity $(15,16)$. In fact, estrogen replacement reduces the increase of the waist to hip ratio after the menopause (17). In premenopausal women the use of modern oral contraceptive agents, containing less than $50 \mu \mathrm{g}$ ethinyl estradiol, is also not associated with weight gain $(18,19)$.

GH deficiency can cause increased body fat mass in adults $(20-22)$. As 10 of the 14 patients had undergone pituitary surgery for Cushing's disease or Nelson's syndrome, it is conceivable that some of them were GH deficient. At present, the biochemical criteria for the diagnosis of GH deficiency in adulthood are not firmly established and are restricted to individuals less than $50 \mathrm{yr}$ old $(23,24)$. For severe GH deficiency in premenopausal women, De Boer et al. (25) proposed to use a cut-off level for plasma GH of less than 15 $\mathrm{mU} / \mathrm{L}$ after provocation with arginine $(0.5 \mathrm{~g} / \mathrm{kg} \mathrm{BW})$. In our study, only 4 of the 13 tested patients had an arginine-stimulated peak plasma GH level greater than $15 \mathrm{mU} / \mathrm{L}$. It remains, however, uncertain whether the other patients are GH deficient, as 8 of them were postmenopausal and older than $50 \mathrm{yr}$ of age. With aging, a substantial decrease in GH responsiveness is present (25), and there are no reliable criteria for $\mathrm{GH}$ deficiency in this group. Furthermore, decreased spontaneous GH secretion and subnormal GH responsiveness are characteristic findings in obese subjects (25) as well as in subjects treated with glucocorticoids, at least in high doses $(26,27)$. However, when we used a cut-off level of 15 or $10 \mathrm{mU} / \mathrm{L}$ with regard to the arginine-stimulated peak plasma $\mathrm{GH}$, there was no difference in \%BF and fat distribution between the groups with the higher and the lower GH responses. Therefore, although it cannot be excluded that in some patients GH deficiency may play a contributory role, $\mathrm{GH}$ deficiency is unlikely to be the most important cause of the increased \% $\mathrm{BF}$ and truncal obesity in the adrenalectomized patients.

In our opinion the truncal obesity in the adrenalectomized patients is most likely the result of glucocorticoid overreplacement. In patients with Cushing's syndrome, hypercortisolism is associated with an excess of visceral and sc abdominal fat. It has been suggested that this is caused by the high density of glucocorticoid receptors in this depot $(28,29)$. There is evidence that cortisol may exert its effect by raising lipoprotein lipase activity. In differentiated human adipocytes as well as in human fat cells in vitro, glucocorticoids enhanced lipoprotein lipase activity, and this effect was 
probably mediated by glucocorticoid receptors (28). Wajchenberg et al. (30) studied body composition data determined by DXA and the abdominal visceral fat component determined by computed tomographic scanning in women with Cushing's disease and compared these data with those from obese women with the same anthropometric parameters. Although patients with Cushing's disease had no increase in total body fat, they had a higher intraabdominal fat area compared to the obese subjects. The total lean tissue mass was slightly reduced in the patients with Cushing's disease compared to that in the obese subjects due to a significant decrease in the muscles of the legs and arms. Lönn et al. (31) reported that pituitary surgery in women with Cushing's disease resulted in a reduction of the total body fat mass. Furthermore, a change in body fat distribution was demonstrated by expressing regional fat mass depots as a percentage of the total body fat mass before and after treatment. After pituitary surgery, the visceral fat mass and sc fat mass of the trunk decreased, which was significantly different from the increase in the fat mass of the legs.

In the adrenalectomized patients in our study, the dosage of glucocorticoids, on the average, $27.3 \mathrm{mg}$ hydrocortisone equivalents / day, although conventionally considered a near optimal amount (32), still might be too high to resolve typical Cushing's symptoms, such as truncal obesity and muscle wasting. None of these 14 patients showed other clinical signs of overtreatment with glucocorticoids. Unfortunately, we do not have body composition data in untreated Cushing's disease patients, nor have such data been reported in literature. Moreover, similar data in patients successfully treated by pituitary adenomectomy are lacking.

Other researchers also found arguments for overreplacement with glucocorticoids, in dosages similar to those used in our study, in patients with primary or secondary adrenal insufficiency. Peacy et al. (33) studied 32 patients receiving glucocorticoid therapy, 12 with Addison's disease and 20 with hypopituitarism. Aiming at peak serum cortisol levels and 24-h urinary free cortisol levels in the normal reference range and avoiding prolonged cortisol troughs, $88 \%$ of the patients required a reduction of the daily glucocorticoid dose and/or a change in glucocorticoid regimen. The mean daily dose of hydrocortisone in this group had to be reduced from $29.5 \pm 1.2$ to $20.8 \pm 1.0 \mathrm{mg}$ to achieve adequate serum cortisol and urinary free cortisol levels. Howlett (34) surveyed case notes of 130 patients receiving glucocorticoid replacement therapy. Considering serum cortisol and urinary free cortisol levels, he concluded that optimal replacement best might be achieved with doses of $20 \mathrm{mg}$ hydrocortisone in 3 divided doses. From these studies, unfortunately, no body composition data for the patients are available.

Whereas the body composition of the patients suggests overdosage of substituting glucocorticoids, bone density data did not differ between the substituted patients and the healthy controls. In a recent study in Dutch Addisonians using similar dosages of glucocorticoids as those used by our adrenalectomized women, BMD was significantly lower in the male patients compared to the control subjects, whereas there was no difference in BMD between female Addisonians and controls (35). In the men with decreased BMD, the daily hydrocortisone dose per $\mathrm{kg}$ BW appeared significantly higher than in men with normal BMD. The researchers suggested that estrogen activity in the females might have prevented glucocorticoid-induced osteopenia. In the study by Peacey et al. (33), BMD at the lumbar spine was significantly lower in a group of 32 patients (13 men and 19 women) receiving glucocorticoid replacement therapy than in ageand sex-matched controls. A weak, but significant, negative correlation was found between BMD and the daily dose of hydrocortisone, expressed as milligrams per $\mathrm{kg}$. Moreover, patients with higher serum cortisol and 24-h urinary free cortisol levels had significantly lower osteocalcin levels. In the patients whose glucocorticoid dose was reduced during the study, the osteocalcin concentration increased significantly, demonstrating that even small changes in cortisol replacement therapy may lead to a change in bone formation. From their data it can be assumed that even mildly excessive glucocorticoid replacement has adverse effects on bone formation and BMD, at least in men. The risk of bone loss during long term treatment with standard replacement doses is another argument for adjustment of glucocorticoid therapy to the lowest acceptable dose.

In conclusion, measurements of body composition in our adrenalectomized patients receiving conventional glucocorticoid substitution showed a markedly increased \%BF with a relatively high amount of truncal body fat and a decreased FFM, whereas BMD was normal. Comparison of body composition measurement methods indicated that rather sophisticated methods, such as DXA, UWW, or $\mathrm{D}_{2} \mathrm{O}$ dilution, are necessary to reliably assess body composition in these patients. More convenient bedside methods, such as BIS and skinfold measurements, did not give reliable body composition data. Although we cannot exclude that GH deficiency might have played a role in some patients, in our opinion the centripetal obesity of the adrenalectomized patients is most likely the result of glucocorticoid overreplacement.

\section{Acknowledgments}

The authors thank L. Wouters of the Department of Human Biology, Maastricht University, for the analyses of the $\mathrm{D}_{2} \mathrm{O}$ samples, and L. van Iersel of the Department of Nuclear Medicine, University Hospital Maastricht, for carrying out the DXA scans.

\section{References}

1. Lukaski H. 1987 Methods for the assessment of human body composition traditional and the new. Am J Clin Nutr. 46:538-556.

2. Füller N, Jebb S, Laskey M, Coward W, Elia M. 1992 Four-component model for the assessment of body composition in humans; comparison with alternative methods, and evaluation of the density and hydration of fat-free mass. Clin Sci Colch. 82:687-693.

3. Fogelholm M, van Marken Lichtenbelt W. 1997 Review: comparison of body composition methods: a literature analysis. Eur J Clin Nutr. 51:495-503.

4. Bouchard C, Després J, Mouriege P. 1993 Genetic and nongenetic determinants of regional fat distribution. Endocr Rev. 14:72-93.

5. Pace N, Rathbun E. 1945 Studies on body composition. III. The body water and chemically combined nitrogen content in relation to fat content. J Biol Chem. 158:685-691.

6. Siri W. 1956 The gross composition of the body. Adv Biol Med Physics. 4:239-280.

7. Westerterp K, Wouters L, Marken Lichtenbelt van W. 1995 The Maastricht protocol for the measurement of body composition and energy expenditure with labeled water. Obes Res. 3(Suppl 1):49-57.

8. Marken Lichtenbelt W van, Westerterp K, Wouters L. 1994 Deuterium dilution as a method for determining total body water: Effect of test protocol and sampling time. Br J Nutr. 72:491-497.

9. Mazess R, Barden H, Bisek J, Hanson J. 1990 Dual-energy x-ray absorpti- 
ometry for total-body and regional bone-mineral and soft-tissue composition. Am J Clin Nutr. 51:1106-1112.

10. De Lorenzo A, Andreoli A, Matthie J, Whithers P. 1997 Predicting body mass with bioimpedance by using theoretical methods: a technological review. J Appl Physiol. 82:1542-1558.

11. Hanai T. 1968 Electrical properties of emulsions. In: Sherman PH, eds. Emulsion science. London: Academic Press; 354-377.

12. Marken Lichtenbelt D. van, Westerterp K, Wouters L, Luijendijk S. 1994 Validation of bioelectrical-impedance measurements as a method to estimate body-water compartments. Am J Clin Nutr. 60:159-166.

13. Durnin J, Womersley J. 1974 Body fat assessed from total body density and its estimation from skinfold thickness measurement on 481 men and women aged 16 to 72 years. Br J Nutr. 32:77-97.

14. Bland J, Altman D. 1986 Statistical methods for assessing agreement between two methods of clinical measurement. Lancet. 1:307-310.

15. Kritz-Silverstein D, Barrett-Conner E. 1996 Long-term postmenopausal hormone use, obesity, and fat distribution in older women. JAMA. 275:46-49.

16. Espeland M, Stefanick M, Kritz-Silverstein D, et al. 1997 Effect of postmenopausal hormone therapy on body weight and waist and hip girths. Postmenopausal Estrogen-Progestin Interventions Study investigators. J Clin Endocrinol Metab. 82:1549-1556.

17. Reubinoff B, Wurtman J, Rojansky N, et al. 1995 Effects of hormone replacement therapy on weight, body composition, fat distribution, and food intake in early postmenopausal women: a prospective study. Fertil Steril. 64:963-968.

18. Carpenter S, Neinstein L. 1986 Weight gain in adolescent and young adult oral contraceptive users. J Adolesc Health Care. 7:342-344.

19. Diffey B, Piers L, Soares M, O'Dea K. 1997 The effect of oral contraceptive agents on the basal metabolic rate of young women. Br J Nutr. 77:853-862.

20. De Boer H, Blok G, Voerman H, de Vries P, van der Veen E. 1992 Body composition in adult growth hormone deficient men, assessed by anthropometry and bioimpedance analysis. J Clin Endocrinol Metab. 75:833-837.

21. Rosén T, Bosaeus I, Tölli J, Lindstedt G, Bengtsson B. 1993 Increased body fat mass and decreased extracellular fluid volume in adults with growth hormone deficiency. Clin Endocrinol (Oxf). 38:63-71.

22. Snel Y, Brummer R, Bol E, et al. 1995 Direct assessment of extracellular water volume by the bromide-dilution method in growth hormone-deficient adults. Eur J Clin Invest. 25:708-714.
23. Ho K, Hoffman D. 1993 Physiology of growth hormone (GH) secretion: implications for the diagnosis of GH deficiency in adults. In: Laron Z, Butenandt $\mathrm{O}$, eds. Growth hormone replacement therapy in adults: pros and cons. London: Freund; 5-16.

24. Cuneo R, Salomon F, Mcgauley G, Sönksen P. 1992 The growth hormone deficiency syndrome in adults. Clin Endocrinol (Oxf). 37:387-397.

25. De Boer H, Blok G, van der Veen E. 1995 Clinical aspects of growth hormone deficiency in adults. Endocr Rev. 16:63-86.

26. Burguera B, Muruais C, Penalva A, Dieguez C, Casanueva F. 1990 Dual and selective actions of glucocorticoids upon basal and stimulated growth hormone release in man. Neuroendocrinology. 51:51-58.

27. Bozzola M, Locatelli F, Gambarana D, et al. 1991 Effect of corticoid therapy on growth hormone secretion. Horm Res. 36:183-186.

28. Rebuffé-Scrive M, Krotkiewski M, Elfverson J, Björntorp P. 1988 Muscle and adipose tissue morphology and metabolism in Cushing's syndrome. J Clin Endocrinol Metab. 67:1122-1128.

29. Björntorp P, Ottosson M, Rebuffé-Scrive M, Xu X. 1990 Regional obesity and steroid hormones interaction in human adipose tissue. In: Bray GA, Ricquier D, Spiegelman BM, eds. Obesity: towards a molecular approach. New York: Liss; $147-158$

30. Wajchenberg B, Bosco A, Marone M, et al. 1995 Estimation of body fat and lean tissue distribution by dual energy $\mathrm{x}$-ray absorptiometry and abdominal body fat evaluation by computed tomography in Cushing's disease. J Clin Endocrinol Metab. 80:2791-2794.

31. Lönn L, Kvist H, Ernest I, Sjöström. 1994 Changes in body composition and adipose tissue distribution after treatment of women with Cushing's syndrome. Metabolism 43:1517-1522.

32. Burke C. 1992 Primary adrenocortical failure. In: Grossman A, ed. Clinical endocrinology. Oxford: Blackwell; 393-404.

33. Peacey S, Guo C, Robinson A, et al. 1997 Glucocorticoid replacement therapy: are patients over treated and does it matter? Clin Endocrinol (Oxf). 46:255-261.

34. Howlett T. 1997 An assessment of optimal hydrocortisone replacement therapy. Clin Endocrinol (Oxf). 46:263-268.

35. Zelissen P, Croughs R, van Rijk P, Raymakers J. 1994 Effect of glucocorticoid raplacement therapy on bone mineral density in patients with Addison disease. Ann Intern Med. 120:207-210. 